\title{
Enhancing content and language integrated learning in post-secondary vocational education
}

\author{
Angel Garralda Ortega ${ }^{1 *}$, Janet Man-wai Cheung ${ }^{2}$, Michelle Yuen-shan Fong ${ }^{1}$ \\ From Practical Social and Industrial Research (PSIR) Symposium 2015 \\ Wan Chai, Hong Kong. 27 November 2015
}

\begin{abstract}
Background
As the Final Report of the Language Education Review highlights, students' low level of English proficiency seriously affects learning in Hong Kong's tertiary institutions and hinders students' potential to fully benefit from English-medium education. This problem is especially serious in self-funded degree programmes, as the students admitted onto these programmes very rarely have scores above 3 on the DSE examinations. This paper reports on a pilot study conducted at THEi aimed at combining Content and Language Integrated Learning (CLIL) and IT innovation to support cognitive and linguistic scaffolding through blended learning.
\end{abstract}

\section{Methods}

The potential benefits of this pedagogical innovation are illustrated in the context of a Year 1 General Education Core Module, The Human Spirit. We investigated learner engagement and the attitudes of teachers and students towards CLIL and blended learning, based on participant observation, Web analytics and survey data [1]. Lectures and tutorials on the human spirit were observed before and during the implementation of CLIL through blended learning, and tutor and student views regarding delivery modes and learning styles were collected during informal discussions throughout the course [2]. Student presentations given in the tutorials, which followed the blended learning component, were also recorded for further study [3]. Google Analytics was used to assess user engagement in e-learning both quantitatively and qualitatively, as the students' work was stored in the system [4]. Forty students selected from among those who were most actively engaged in blended learning were surveyed to explore

\footnotetext{
* Correspondence: agarralda66@vtc.edu.hk

'School of General Education and Languages, Technological and Higher

Education Institute of Hong Kong, Hong Kong

Full list of author information is available at the end of the article
}

their perceptions of whether blended learning was more time consuming and more effective than traditional lectures and tutorials.

\section{Results}

As the teachers' perceptions of key components of blended learning, such as flipping classes, proved to be ambivalent during the course of the project, blended learning was eventually made optional alongside the traditional delivery mode of lectures and tutorials. Student engagement in blended learning varied from group to group, as reflected in the number of page views and the activities engaged in. Nearly $60 \%$ of the students used some form of blended learning and almost $40 \%$ tried both the reading and the listening component. The listening component proved to be slightly more popular and was also considered more useful than the reading component, as reflected in the level of user engagement and in a perception survey conducted at the end of the project.

More than half of the students expressed that blended learning improved their comprehension of the subject, helped them to develop language proficiency and eased their workload. However, when asked to choose between blended learning and traditional learning, only about half of the respondents preferred this novel delivery mode and over a third remained non-committal.

\section{Conclusions}

The results of this pilot project indicate that using blended learning in combination with CLIL may be effective, but factors such as pedagogical constraints, learner motivation and teacher/student attitudes and agendas must be carefully considered for pedagogical innovation to succeed. 


\section{Authors' details}

'School of General Education and Languages, Technological and Higher Education Institute of Hong Kong, Hong Kong. ${ }^{2}$ Research Support Unit, Vocational Training Council, Hong Kong.

Published: 27 November 2015

\section{References}

1. Cummins J: The construct of language proficiency in bilingual education.

In Perspectives on Bilingualism and Bilingual Education. Washington DC:

Georgetown University Press;Alatis JE, Staczek JJ 1985:209-231.

2. Rogers EM: Diffusion of Innovations New York: Free Press; 2003.

3. Standing Committee on Language Education and Research (SCOLAR): Action plan to raise language standards in Hong Kong: final report of language education review. Hong Kong: Hong Kong Government Documents 2003.

doi:10.1186/2193-1801-4-S2-03

Cite this article as: Garralda Ortega et al:: Enhancing content and language integrated learning in post-secondary vocational education. SpringerPlus 2015 4(Suppl 2):03.

\section{Submit your manuscript to a SpringerOpen ${ }^{\mathcal{O}}$ journal and benefit from:}

- Convenient online submission

- Rigorous peer review

- Immediate publication on acceptance

- Open access: articles freely available online

- High visibility within the field

- Retaining the copyright to your article

Submit your next manuscript at $\gg$ springeropen.com 